\title{
Idrættens og sportens socialhistorie i Århus ca. 1880 til i dag.
}

\section{Et igangværende projekt.}

\author{
Jørn Hansen.
}

Denne artikel omhandler et projekt, der først inden for det sidste halve år har taget form, og derfor på mange måder stadig befinder sig $i$ idefasen. Projektbeskrivelsen er som sådan ideel og foreløbig. Projektet har været forelagt til diskussion på seminaret om „Idrætten i lokalhistorien“ i Vejle d. 18-20 oktober 1985.

Vi har i Danmark en lang tradition for lokalhistoriske studier, en tradition som det her beskrevne projekt ingen intention har om at ,,gøre op med", men som det alligevel på mange punkter vil være forskellig fra! Alene ved at det lokalhistoriske rum er en større by. Almindeligvis har lokalhistorikerne beskæftiget sig med sogne- og egnshistorie, altså udviklingen på landet blandt husmænd og bønder, jvf. hertil Niels Kayser Nielsens og Verner Bruhns arkikler.

Jeg vil i det følgende skitsere:

1. Indfaldsvinklen til projektet.

2. Hypoteserne på indeværende tidspunkt.

3. Materialet undersøgelsen kommer til at bygge på.

4. Fremgangsmåden - hvorledes en gruppe vil forsøge at indløse projektet.

II

1.

Indfaldsvinklen til projektet er socialhistorisk. I min artikel i sidste års årbog argumenterede jeg for en socialhistorisk indfaldsvinkel til studiet af idrætshistorien. Udgangspunktet for projektet er: at idrætshistorie ikke bør være "historie fra oven «; at man skal beskæftige sig med idrætshistorien som en social og kulturel foreteelse i dagligdagen; at man skal efterspore spændingsfeltet mellem historie og idrætshistorie, undersøge om idrætshistorien altid er en harmonisk integreret del af samfundshistorien; påvise hvilke elementer i idrætshistorien, der er systemtilpassende, og hvilke der er 


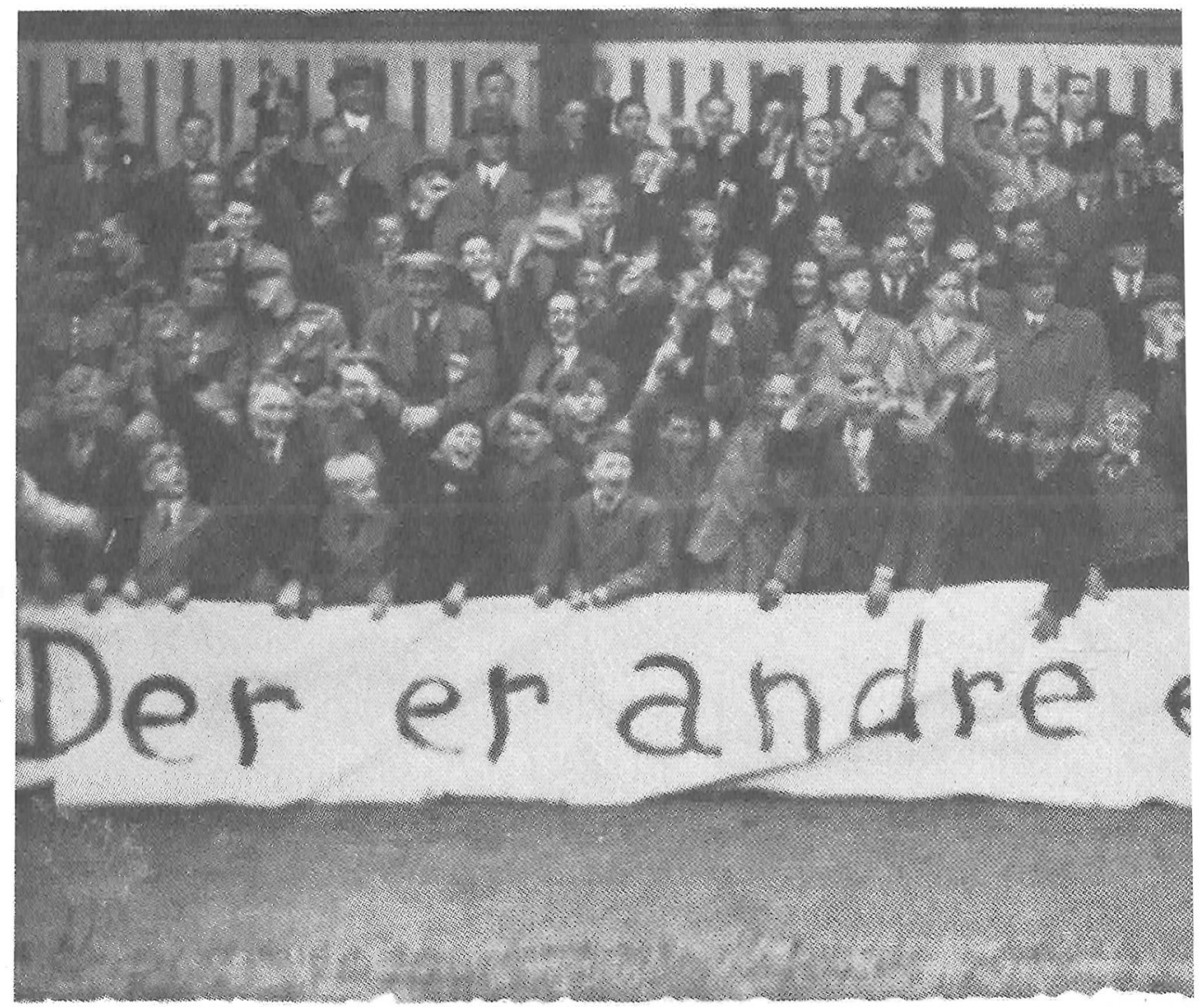

„Der er andre end AGF der dur̆“. Transparent fra AlAs̀ tilhængere på Århus stadion. Fra en samling af Aage Fredslund Andersens sportsbilleder fra 1930èrne. (Lokalhistorisk samling.)

frigørende, herunder hvilke befolkningsgrupper knytter de systemtilpassende elementer sig til, og hvilke befolkningsgrupper knytter de frigørende elementer sig til. (Jvf. ,Idrætshistorisk Årbog nr. 1" s. 26).

En sådan socialhistorisk indfaldsvinkel med ønsket om at se historien fra neden bliver imidlertid til en uoverskuelig opgave, hvis undersøgelsen ikke netop foregår i lokalhistorisk regi. Hertil kommer, at det er min opfattelse, at udviklingen inden for Århus By og Amt eksemplarisk afspejler den generelle udvikling inden for idrætten og sporten i Danmark. Projektet vil således komme til at fremstille idrættens og sportens ",rigshistorie“ i lokalhistorisk regie. 


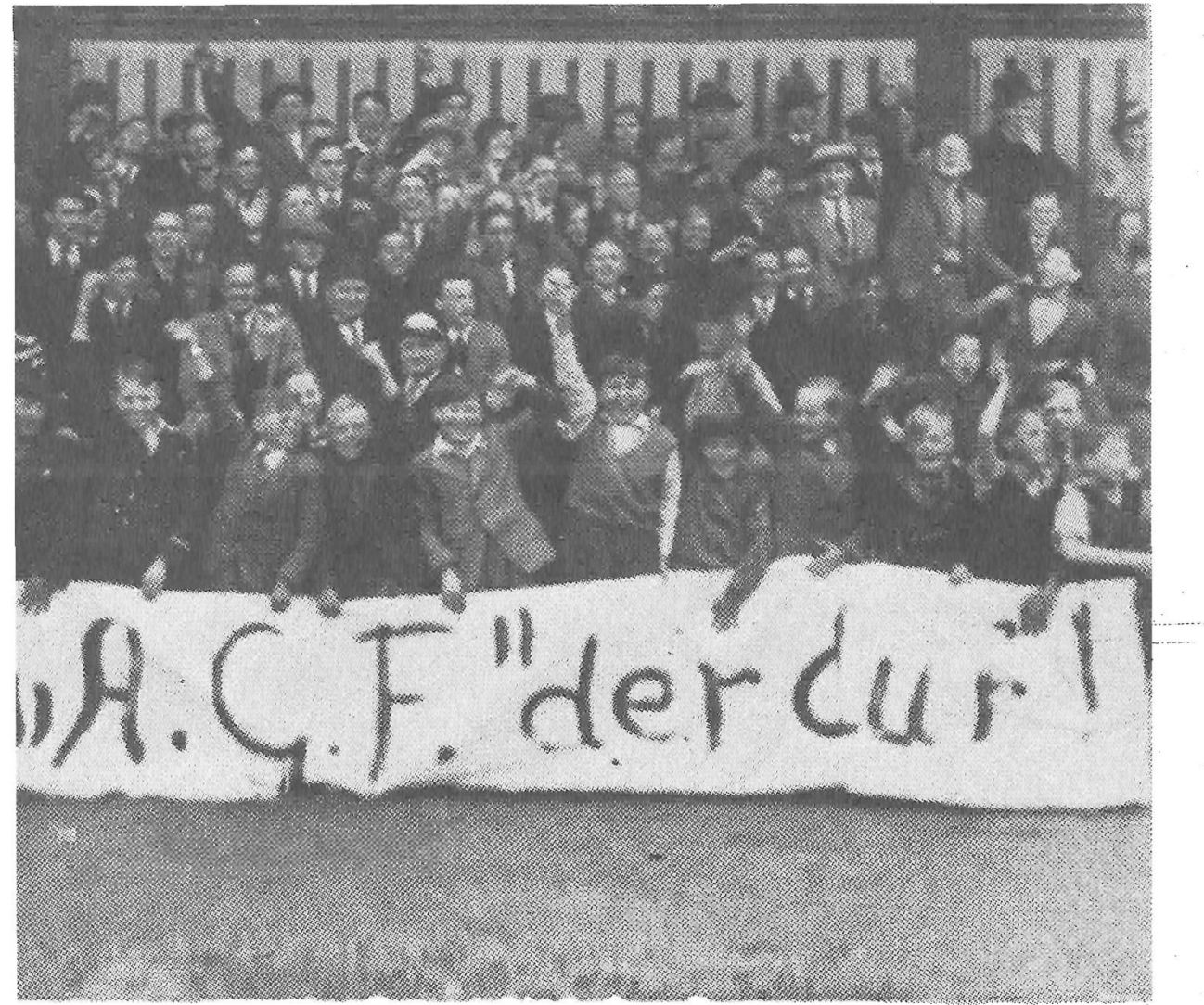

2.

Når vi har valgt at begynde undersøgelsen/fremstillingen omkring 1880 hænger det sammen med, at sporten fra dette tidspunkt begynder at vinde indpas i Århus. Århus Gymnastikforening (AGF) dannes i 1880 som den første forening, der tager konkurrencesporten på programmet. Frem til århundredeskiftet må idrætten siges at være den fremherskende legemskultur i Århus By og Amt. I begyndelsen af dette århundrede vinder sporten større og større udbredelse og kan fra mellemkrigstiden siges at være den fremherskende legemskultur i Århus By og Amt.

Hvad angår forholdet mellem idræt og sport knytter jeg an til Torben Jacobsens definitioner af de to begreber: Ved idræt forståes de organiserede 
legemlige aktiviteter, der udøves med en alsidig fysisk udvikling for øje, og som opstiller ideelle mål, udover disse rent legemlige, af psyko-social eller politisk-ideologisk art.

Ved sport forståes de organiserede legemlige aktiviteter, der udøves i specialiseret retning og (på nær visse sundhedsider) ikke opstiller andre mål end videre udvikling og forbedring af disse aktiviteter, især med henblik på bedre konkurrenceresultater.(,,Idrætshistorisk Årbog nr. 1“"s. 127).

I kraft med udviklingen henimod sportens dominans dannes forskellige klubber og foreninger, der ud fra en socialhistorisk indfaldsvinkel kan karakteriseres som borgerklubber (eksempelvis allerede omtalte AGF, der også går under betegnelsen ,de fine“), arbejderklubber (eksempelvis Arbejdernes Idrætsklub i Århus (AIA) og Arbejder Sport Århus (ASA)) og kvartersklubber/lejrklubber (eksempelvis Skovbakken (Trøjborgkvarteret), Fuglebakken (Frydenlundskvarteret) og Christiansbjerg Boldklub (et udpræget „,rabarberkvarter"). Grænsen mellem arbejderklubber er selvfølgelig flydende, inddelingen tager først og fremmest udgangspunkt i situationen omkring foreningens eller klubbens grundlæggelse. Vi vil undersøge udviklingen $i$ disse kategorier af klubber; deres medlemsbasis, deres ledere, hvilke discipliner farvoriseres, hvad betyder ændringerne i deres geografiske placering, evt. fusionering med forstadsklubber/foreninger (AIA er blevet til AIA/Tranbjerg, Fuglebakken til Idrætsklubben Hasle-Fuglebakken (IHF)).....

At sporten med tiden kommer til at dominere over idrætten kan dokumenteres ved at vise, hvorledes de folkelige idrætsforeninger, ofte mod ledernes ønsker, af medlemmerne tvinges til at tage konkurrencesport som fodbold på programmet. Dertil kommer, hvorledes Århus By i løbet af perioden bygger idrætsfasciliteter, der begunstiger konkurrencesporten.

En socialhistorisk indfaldsvinkel til idrættens og sportens historie bør ud over den allerede omtalte kategorialisering af klubberne også indeholde en typeinddeling af disciplinerne i f.eks. borgerdiscipliner (tennis, sejlsport ...), arbejdersport (boksning, vægtløftning ...) og massesport (fodbold, håndbold ...). Holder denne inddeling og hvilken udvikling er der sket?

3.

En undersøgelse af idrættens og sportens socialhistoriske udvikling i Århus er aldrig tidligere foretaget. By-historisk selskab har ikke beskæftiget sig hermed; og i den sidst udgivne fremstilling af „Århus Bys Historie“" fra 1984 behandles idrættens og sportens betydning kun overfladisk. Dette endda selv om forfatterne vil beskæftige sig med ,,... de dominerende eller karakteristiske sociale, kulturelle og politiske bevægelser, tendenser og ikke mindst modsætninger". (, ,Århus Bys Historie - fra vikingetid til nutid"s. 9). Allerede i sin disputats fra 1974 ,Idrottens väg til folkrörelse“ bestemmer J. Lindroth 
idrætten som en af det 20. århundredes store bevægelser.

Hertil kommer at egentlige samlede fremstillinger om idrættens generelle historie heller ikke findes. Der findes fremstillinger skrevet i forbindelse med enkelte klubbers jubilæer. Disse jubilæumsskrifter beskriver først og fremmest organisatoriske forhold, opnåede resultater, samt hylder de ledere, der har været $\mathrm{i}$ spidsen for klubben/foreningen.

En egentlig viden om idrættens og sportens historie i Århus opnåes først ved at gå til de primære kilder. Vi er her så heldige, at Erhvervsarkivet de sidste par år har indsamlet arkiver fra foreninger i Århus. En liste over de idræts og sportsforeningers eller klubbers arkiver, der findes i Erhvervsarkivet bringes som bilag 1 til artiklen.

Materialet fra Erhversarkivet suppleres af andet arkiv-materiale fra ,lokalhistorisk" samling v. Hovedbiblioteket. Dette arkiv besidder blandt andet en stor samling af billeder af idrætten og sporten i Århus.

Udover foreningsarkiver og jubilæumsskrifter findes der $\mathrm{i}$ avisernes dækning af idræts og sportsbegivenheder et omfattende materiale. Især artikler fra før T.V.'s udbredelse vil være relevant. Før T.V.'s udbredelse bestræbte sportsjournalisterne sig i højere grad på at skildre miljøet omkring og handlingsforløbet under sportsbegivenhederne; hvorimod T.V.'s udbredelse har ført til en orientering mod enkelte personers betydning.

$\mathrm{Vi}$ er $\mathrm{i}$ den heldige situation, at vi har mulighed for at udbygge vores skriftlige kilder med interviews. Dette er dels en kvalitativ udvidelse af materialet, men også en uomgængelig udvidelse, hvis vi vil indløse kravet om at se historien ,fra neden“. Vi vil interviewe flere ældre tidligere aktive eller passive idrætsudøvere om sportens kulturmiljø. Vigtigt er det her at få fat $\mathrm{i}$ medlemmer, der ikke nødvendigvis har været udøver på eliteplan eller ledere; personer der måske ikke har gjort sig synderligt bemærket, men hvor hele deres fritid har været fyldt ud af sporten eller idrætten. Hvilken identitet har idrætten eller sporten givet dem, hvad har de betydet for idrætten eller sporten? Vi kender alle f.eks. de personer, der kridtede baner af, passede boldene og bare altid var der uden at gøre sig synderligt bemærket.

Med hensyn til selve Århus Bys økonomiske og sociale historie er der ikke de store problemer med materialet. Der findes i forvejen en række fremstillinger, som kan anvendes til at udgøre den ramme idrættens og sportens socialhistorie skal placeres $\mathrm{i}$ forhold til.

4. Indledningsvis nævnte jeg, at vi er en gruppe, der vil arbejde med projektet. Gruppen består af Karl Christensen, Claus Nielsen, Kurt Klaudi, Poul Porskjær og undertegnede. For tiden kan vi involvere os i projektet med varierende arbejdsintensitet. 
På indeværende tidspunkt (oktober 85) er vi så småt begyndt at kigge på udvalgte arkiver. Vi har foreløbig udvalgt de arkiver, hvor vi mener vi bedst kan få verificeret eller falsificeret vores hypoteser. Hvilke vil fremgå af bilag 2. Af bilaget vil også fremgå, hvilket materiale i arkiverne der i første omgang har vores interesse: Vedtægter, forhandlingsprotokoller, korrespondance og medlemsbøger eller protokoller. Især medlemsbøgerne er vigtige for at kunne danne sig et overblik over medlemmernes sociale placering.

For at få lov til at anvende arkiverne har vi skullet indhente tilladelse hos de respektive foreninger eller klubber. Generelt er vi blevet modtaget med stor entusiasme og med tilbud om evt. bistand $\mathrm{i}$ søgningen efter yderligere materiale.

I november måned vil vi dels gennem direkte henvendelse til de omtalte klubber og foreninger og dels gennem annoncering indkalde til et møde i et af Århus Stadions mødelokale, hvor vi vil orientere om vores projekt. Vi håber derigennem at kunne få etableret et kontaktnet, der kan være os nyttigt, når vi skal til at finde personer, der skal interviewes. Vores næste skridt efter mødet i november vil være at undersøge forskellige muligheder for at få tilskud til projektet.

Tilbage er så blot håbet om, at vi besidder tilstrækkelig med kondition til at kunne indløse projektet. 


\section{Anvendt litteratur:}

- Idrætshistorisk Årbog 1985, nr. 1. Dansk Idrætshistorisk Forening Krop og Kultur.

- Den Jyske Historiker nr. 19-20 ,,Sportshistorie" 1981.

- Helge Paludan m.fl. „Århus Bys Historie - fra vikingetid til nutid“, Husets Forlag 1984.

- J. Lindroth: „Idrottens väg til folkrörelse. Studier i svensk idrottsrörelse til 1915“, Uppsala 1974.

Status oktober 1985 over de idrætslige foreninger hvis arkiver befinder sig i ERHVERVSARKIVET.

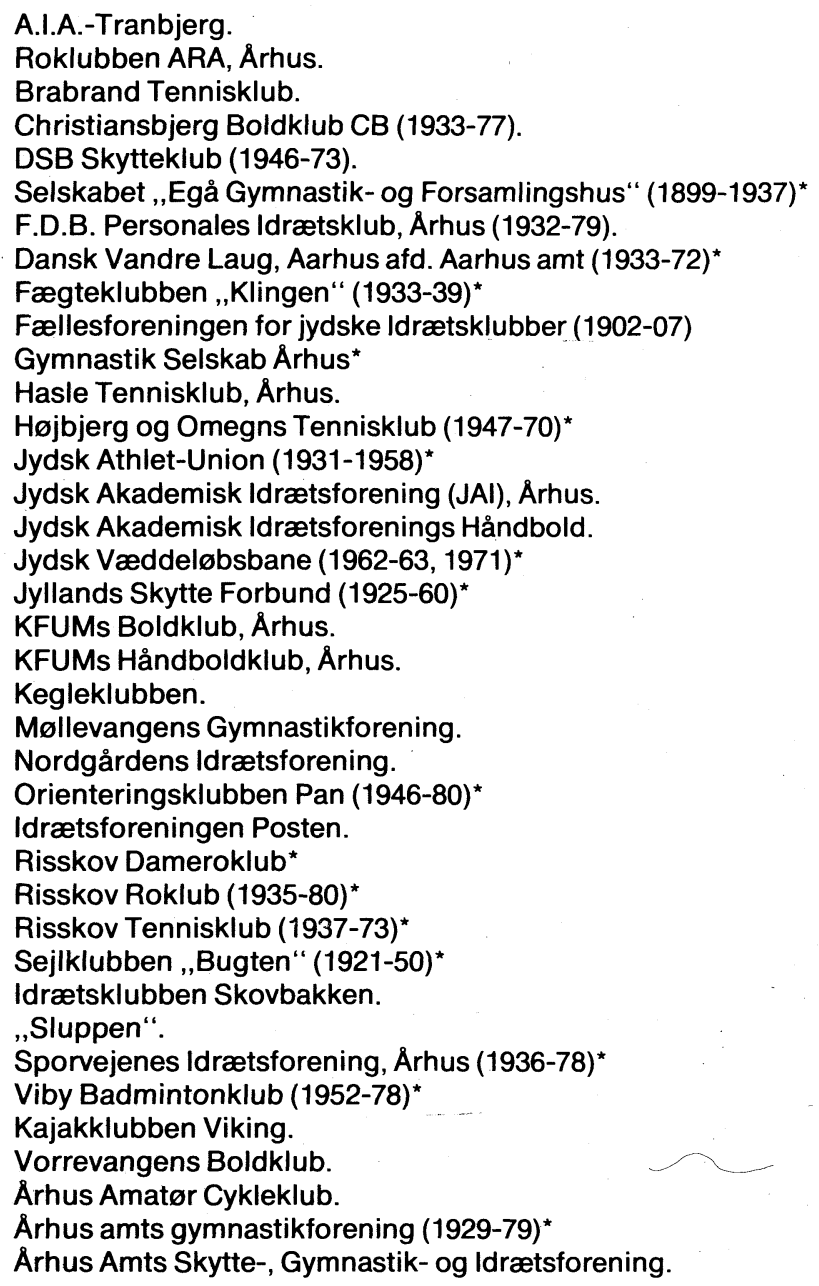


Århus Automobilsport (ÅAS).

Århus Boldklub (1916-79).

Aarhus Boldspil-Union (ABU) (1926-79)*

Århus borgerlige Skydeselskab (1927-71)*

Århus Dame Roklub (1922-80)*

Århus FDF Boldklub (1957-74)*

Århus Faldskærms Klub.

Århus firmasport (1950-78).

Aarhus Flyveklub.

Århus Garnisons Idrætsforening (1927-77).

Aarhus Gymnastik Forening (AGF) (1880-1980).

Århus Idrætslærerforening (1962-79)*

Sejlsportsforeningen „Aarhus Kystpatrouille“.

Århus pistolklub (1961-77)*

Århus Rideklub (1922-79)*

Århus Roklub (1889-1979)*

Århus Skyttekreds (1916-20)*

Århus Studenter Gymnastik ASG (1970-79)*

Aarhus Svæveflyveklub.

Skydeselskabet ,Minerva“ (1883 ff)*

Århus Travklub (1929-72)*

Århus Universitets Sport (AUS).

* betyder at arkivet (endnu) ikke er ordnet.

AIA

Forhandlingsprotokoller 1918-70 (3 bd.)

Forhandlingsprotokoller (fodbold) 1936-67 (5 bd.)

Forhandlingsprotokoller vedr. tilskuerklub 1939-68 (1 bd.)

Medlemsbøger 1944-71 (2 bd.)

Medlemsblade 1920-78 (2 pk.)

Korrespondance 1934-78 (2 pk.)

Idrætsudstilling, klubhus, korrespondance vedr. sammenslutning 1938-78 (1 pk.)

Scrapbog vedr. 25 ås jubilæum 1943 (1 pk.)

Manus, vedr. 50 års jubilæum 1968 (1 pk.)

Telegrammer vedr. 50 års jubilæum (1 pk.)

$C B$ (Christiansbjerg boldklub)

Forhandlingsprotokoller 1933-77 (5 bd.)

Medlemsbøger 1933-60 (4 bd.)

Hovedbog 1933-40 (1 bd.)

Korrespondance 1958-73 (6 pk.)

Medlemsblade 1933-75 (2 pk.)

Byggesager 1961-74 (3 pk.)

Avisudklip 1965-74 (1 pk.)

Fællesforeningen for jydske idrætsklubber

Regnskabs- og brevjournal (1 bd.) 


\section{KFUM's Boldklub}

Forhandlingsprotokoller 1938-67 (3 bd.)

Materiale vedr. foreningens bestyrelse 1960-83 (1 pk.)

Medlemsprotokol 1939-50 (1 bd.)

Korrespondance 1937-63 (2 pk.)

Diverse materiale 1944-69 (1 pk.)

Idrætsklubben Skovbakken

Forhandlingsprotokoller 1927-49 (3 bd.)

Vedtægter og mødereferater 1953-81 (1 pk.)

Mødereferater 1962-81 (1 pk.)

Korrespondance 1962-81 (5 pk.)

Materiale vedr. Idrætshøjskolen 1967-75 (1 pk.)

Århus Amts Gymnastikforening

Forhandlingsprotokoller 1929-79

Fortegnelse over kredsformænd 1936-61 (1 bd.)

Medlems- og kontingentbog 1938-61 (1 bd.)

Medlems- og formandsliste 1963-75 (2 pk.)

Foreningsskemaer 1961-76 (2 pk.)

Sager vedr. opvisning m.v. 1936-81 (3 pk.)

Korrespondance 1958-82 (6 pk.)

Medlemsblade 1946-58 (1 bd.)

Arhus Amts Skytte-, Gymnastik- og Idrætsforening

Forhandlingsprotokoller 1866-74 (2 bd.)

\section{Århus Boldklub}

Medlemsprotokoller 1916-52 (1 bd.)

Kassebøger 1916-17 (1 bd.)

\section{Århus Boldspil Union}

Forhandlingsprotokoller 1926-79 (2 bd.)

Love, årsberetninger, årsregnskaber 1926-75 (1 pk.)

Scrapbøger 1930-49 (2 bd.)

\section{Århus Gymnastik Forening (AGF)}

Forhandlingsprotokoller fra bestyrelsen 1880-1966 (4 bd., 1 pk.)

Forhandlingsprotokoller for fodboldafdelingen 1920-68 (7 bd.)

Forhandlingsprotokoller for baneudvalg 1935-59 (1 bd.)

Medlems- og kontingentbøger 1880-1922 (8 bd.)

Medlemsbøger 1922-42 (6 bd.)

Bog over entreindtægter 1920-27 (1 bd.)

Protokol for AFG's idrætsanlæg 1922 (1 bd.)

Sager vedr. idrætsstævne og turneringer 1889-1975 (1 pk.)

Protokol over indkomne breve 1901-08 (1 bd.)

Korrespondance 1908-77 (4 pk.)

Sager vedr. bygning af nyt klubhus 1940-42 (1 pk.)

Diverse sager 1909-80 (1 pk.)

Diverse sager 1924-70 (1 pk.) 


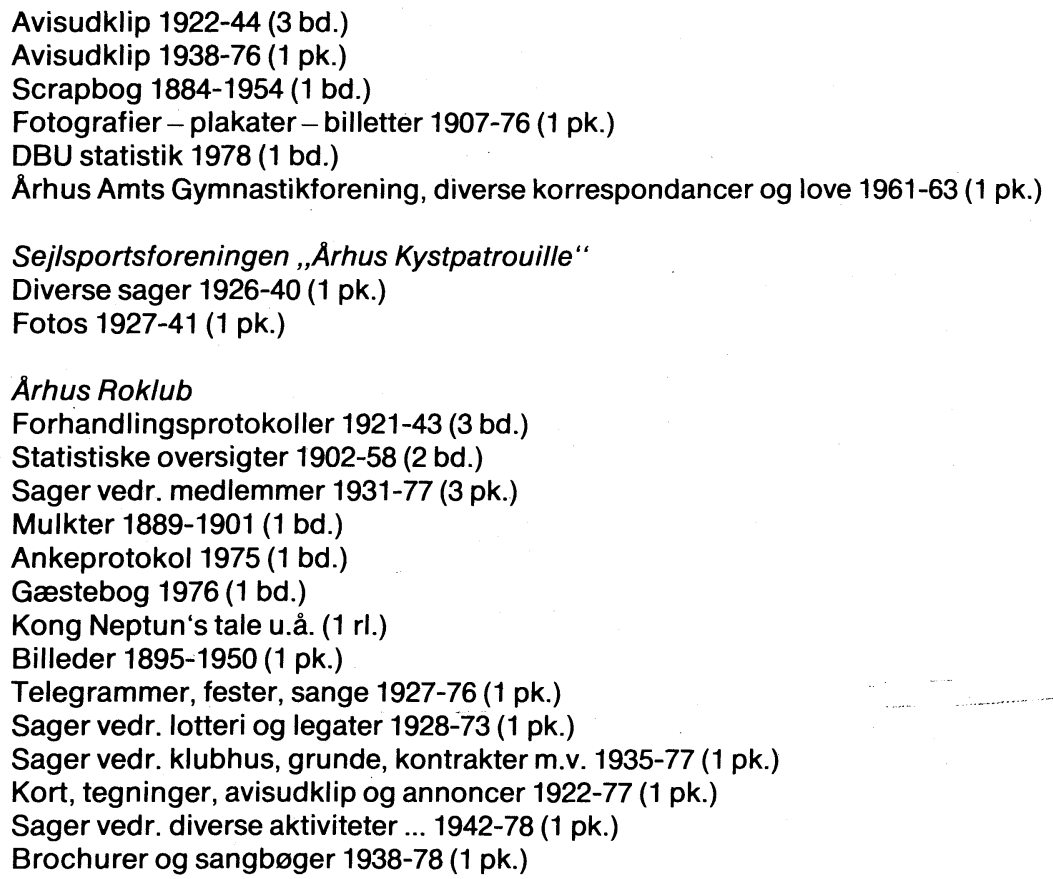

